\title{
Diet of Tadpoles of Microhyla ornata (Dumeril and Bibron,1841) from a Freshwater System in Rosekandy Tea Estate, Cachar, Assam and Significance of Conservation of Aquatic Habitats
}

\author{
MITHRA DEY* and SHWETA GOSWAMI \\ Department of Ecology and Environmental Science, Assam University, Silchar-788011 Assam, India. \\ http://dx.doi.org/10.12944/CWE.10.1.28
}

(Received: November 18, 2014; Accepted: February 24, 2015)

\begin{abstract}
Anuran tadpoles are gregarious in nature and knowledge of food and feeding behavior of the tadpoles is very essential for their successful breeding and survival. Dramatic declines in amphibian populations have been noted since 1980 from all over the world and are thus perceived to be one of the most critical threats to global biodiversity. Microhyla ornata commonly known as Ornamented Pygmy Frog, belongs to Family- Microhylidae and is widespread species occurring throughout South Asian countries like Bangladesh, India, Myanmar, Pakistan, Sri Lanka as well as in Japan. Considering the occurrence of tea plantation in the region and the presence of aquatic bodies in tea estates it is necessary to know the feeding habit of the anuran tadpoles and impact of unavailability of suitable food items which will affect the survival and completion of life cycle of the tadpoles. In the present study it was observed that Microhyla ornata tadpoles feed mainly on various algae (25 genera) and detrital material. Hence, it may be concluded that aquatic habitats must be conserved and maintained so that conservation of anurans can be ensured.
\end{abstract}

Key words: Feeding behaviour, Algae, Detritus, Chlorophyceae, Cyanophyceae, Bacillariophyceae, Shannon-Weiner Index, Berger- Parker Diversity Index, Conservation.

\section{INTRODUCTION}

Anuran tadpoles are gregarious in nature (Saidapur, 2001). Knowledge of food and feeding behavior of the tadpoles is very essential for their successful breeding, as the early part of life history of amphibians is dependent on the availability of food items in the natural habitat (Sinha et.al., 2001) Dramatic declines in amphibian populations have been noted since 1980 from all over the world and is thus perceived to be one of the most critical threats to global biodiversity. A number of causes are believed to be involved including habitat destruction, impact of pesticides, over exploitation, pollution, introduction of exotic species, climate change, destruction of the ozone layer etc. Feeding constitutes an important aspect in the biology of anuran tadpoles. Most tadpoles are primarily herbivorous (Duellman and
Trueb, 1986) consuming a wide variety of algal taxa as well as detritus, viruses, bacteria, protists, plant fragments, pollen grains, fungi, various kinds of small animals, anuran eggs, and other tadpoles (Kupferberg et al., 1994) and feed on whatever is available in the system they inhabit and food plays an important role in habitat partitioning (Heyer, 1972; Seale and Beckvar, 1980) . In north-east India, only a few studies have been conducted on food habit of tadpoles (Chanda 1993; Bordoloi \& Kalita 1998; Dey, 2008; Sinha et al,2001; Narzary and Bordoloi,2012). Dey (2008) observed dietary overlap and degree of selective feeding in four different anurans tadpoles. Microhyla ornata commonly known as Ornamented Pigmy Frog belongs to Family- Microhylidae. It is a widespread species occurring through most of South Asian countries like Bangladesh, India, Myanmar, Pakistan, Sri Lanka as well as in Japan. 
The present study describes the qualitative and quantitative analysis of food consumed by the tadpoles of Microhyla ornata from a tea estate. Water samples were also analysed to understand the food availability and to find out if there is any special preference. The study on food preference of the tadpoles will be helpful for conservation of water bodies and ex-situ conservation of the anurans. Aquatic bodies must have requisite amount of food items which will provide sufficient energy and enhance the trophic status required for the development and completion of life cycle of the tadpoles. Considering the use of various insecticides, pesticides and herbicides in tea gardens the qualitative preservation of aquatic bodies which serve as breeding habitats for the anurans is very significant.

\section{MATERIALS AND METHODS}

The Rosekandy Tea Estate is situated at Barjalenga in Cachar district of Assam. It is geographically located within 2442'29"-2441'31" North and $92^{\circ} 41^{\prime} 52^{\prime \prime}$ - $92^{\circ} 42^{\prime} 39^{\prime \prime}$ East. The maximum temperature in the study area ranged from $23^{\circ} \mathrm{C}$ $34.4^{\circ} \mathrm{C}$; minimum temperature from $11.4^{\circ} \mathrm{C}-26^{\circ} \mathrm{C}$; and relative humidity between $60.4 \%-96 \%$. The total area under the tea estate is about 1702.01 hectares; out of which, 562.80 hectares area is used at present for tea plantation while the rest 1309.78 hectares area consists of uncultivated lands, secondary forest and water reservoirs. The different vegetation types and plantation patterns result in the formation of various microhabitats in the tea gardens where different species of anurans have been recorded. The tea estate contains many large and small water reservoirs, ponds and natural streams which stores water during the rainy season. This stored water is used during dry season to irrigate the tea gardens. These water bodies form ideal habitat and breeding ground for different species of anurans. The climate of the region is subtropical and humid and experiences average rainfall of $2660 \mathrm{~mm}$. The rainy season extends from March to September with peak rainfall between May to September; most of which is received from the Southwest monsoon; December to February is the dry period.

Tadpoles of Microhyla ornata were collected by hand net of mesh size $1 \mathrm{~mm}$ from a temporary pool and immediately fixed in $10 \%$ formalin to stop the digestion. The pool was man-made, ephemeral, isolated and was connected to a drain of tea garden as well as the pond nearby; it was exposed to direct sunlight. The pool was $5 \mathrm{ft}$ in breadth with had a depth of $1 / 2 \mathrm{ft}$. Large number of tadpoles of Microhyla ornata were found. Not a single individual of any other anuran tadpole was found in that pool. Microhyla ornata is found to breed nearly throughout the year and in clear aquatic systems. The pool shore was lined with small shrubs and visible submerged terrestrial shrubs and vegetation. The vegetation found in and around the pool were Mimosa pudica, Urena lobota, Paspalum sp.

The gut of each tadpoles were dissected, the contents were transferred to a watch glass and mixed with $0.5 \mathrm{ml}$ of water. One drop of gut content was placed on a glass slide, covered by a coverslip and examined under microscope (10x, 40x). Five to eight subsamples were examined for each specimen. Total of 10 tadpole guts was examined. All food items were expressed in terms of percent abundance and percent frequency of occurrence (Dey, 2008).

The degree of dominance of food items in stomach sample was calculated by Berger- Parker Diversity Index which is as follows:

$$
\mathrm{D}=\mathrm{Nmax} / \mathrm{N}
$$

where, $\mathrm{N}=$ the total no. of individuals \& Nmax $=$ the no. of individual in the most abundant resource.

The species diversity is calculated by Shannon-Weiner Index

$$
\mathrm{H}^{\prime}=-\Sigma \text { pi In pi }
$$

Where, $\mathrm{pi}=$ proportional abundance of the ith species $=(\mathrm{ni} / \mathrm{N})$.

The species evenness is calculated by

$$
\mathrm{E}=\mathrm{H}^{\prime} / \ln \mathrm{S}
$$

Where $S=$ total no. of individual.

Water samples were also collected and fixed in $10 \%$ formalin and examined under compound microscope. Identification of food items found in the gut of tadpoles and organisms found in water sample was done following standard literatures (Edmondson, 1956 and Smith, 1994). Food items were identified upto genus level. 


\section{RESULTS AND DISCUSSION}

The tadpoles of $M$. ornata are white to pale cream in colour, and transparent with melanophore deposition on the dorsum, tail and tail fins. The snout is broadly rounded, eyes lateral with naris nearer to the eye than to the tip of the snout. The intestine is clearly visible in the transparent body. The mouth is terminal in position and does not possess jaws, no keratodont and hard parts are present in the oral disc. The tail is transparent with a caudal and a dorsal fin.

Table 1: The qualitative and quantitative list of food items found in the gut of tadpole and percent relative abundance and percent frequency of occurrence

\begin{tabular}{|c|c|c|c|}
\hline Food items & $\begin{array}{c}\text { No. of } \\
\text { organisms }\end{array}$ & $\begin{array}{c}\text { Percent Frequency } \\
\text { of occurrence }\end{array}$ & $\begin{array}{c}\text { Percent } \\
\text { Abundance }\end{array}$ \\
\hline Chlorophyceae & & & 47.60 \\
\hline Closterium sp. & 572 & 96 & 29.43 \\
\hline Euastrum sp. & 80 & 66 & 4.11 \\
\hline Stuarstrum sp. & 21 & 10 & 1.08 \\
\hline Cosmarium sp. & 80 & 74 & 4.11 \\
\hline Spirogyra sp. & 21 & 34 & 1.08 \\
\hline Pediastrum sp. & 07 & 8 & 0.36 \\
\hline Docidium sp. & 54 & 58 & 2.77 \\
\hline Ecallocystis sp. & 01 & 2 & 0.05 \\
\hline Ankiosdesmus sp. & 54 & 36 & 2.77 \\
\hline Mougeotia sp. & 21 & 22 & 1.08 \\
\hline Scenedesmus sp. & 05 & 10 & 0.25 \\
\hline Ulothrix sp. & 03 & 6 & 0.15 \\
\hline Zygnema sp. & 03 & 4 & 0.15 \\
\hline Volvox sp. & 01 & 2 & 0.05 \\
\hline Bacillariophyceae & & & 41.79 \\
\hline Navicula sp. & 236 & 92 & 12.14 \\
\hline Pinnularia sp. & 270 & 100 & 13.89 \\
\hline Gomphonema sp. & 195 & 90 & 10.03 \\
\hline Cymbella sp. & 70 & 36 & 3.60 \\
\hline Nitzschia sp. & 02 & 2 & 0.10 \\
\hline Tabellaria sp. & 22 & 24 & 1.13 \\
\hline Cyclotella sp. & 12 & 18 & 0.61 \\
\hline Eunotia sp. & 01 & 2 & 0.05 \\
\hline U.I. diatom & 04 & 6 & 0.20 \\
\hline Cyanophyceae & & & 6.94 \\
\hline Nostoc sp. & 01 & 2 & 0.05 \\
\hline Oscillatoria sp. & 15 & 18 & 0.77 \\
\hline Other blue-green algae & 116 & 58 & 5.97 \\
\hline Detritus & 35 & 50 & 1.80 \\
\hline Unidentified & 33 & 48 & 1.69 \\
\hline
\end{tabular}

Tadpoles of Microhyla ornata depend basically on phytoplankton. The gut of all the tadpoles examined was found to contain phytoplanktons and detritus. No zooplanktons were found. A total no of 1943 individuals belonging to 26 genera of Chlorophyceae, Cyanophyceae and Bacillariophyceae were recorded in the tadpole guts. Along with these detritus and some unidentified items were also found. The most frequent and abundant green algae are Closterium, Cosmarium, Euastrum etc. Among the Diatoms Pinnularia, 
Table 2: Estimates of Berger-Parker diversity Index (1/d= reciprocal form), Shannon-Weiner Diversity Index(H ì) and Evenness (E) in the gut of Microhyla ornata

\begin{tabular}{llll}
\hline & 1/d & H $^{\prime}$ & E \\
\hline Microhyla ornata & 3.26 & 2.37 & 0.31 \\
\hline
\end{tabular}

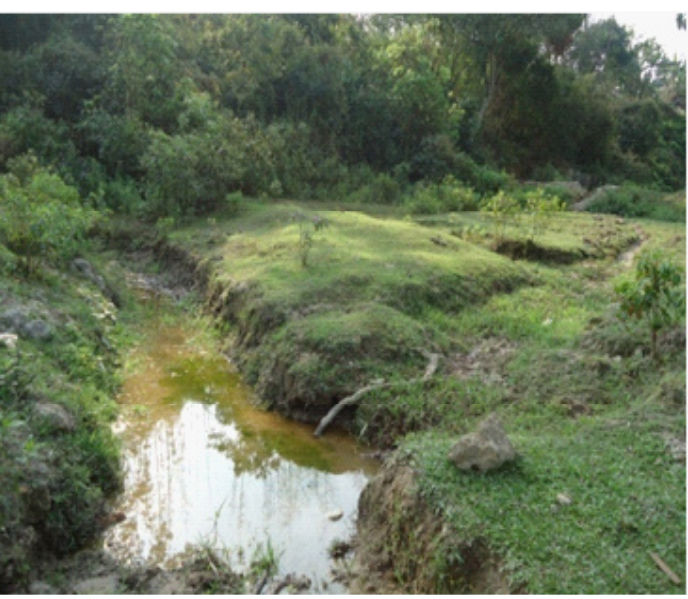

Fig. 1a: Temporary Pool
Table 3: Estimates of Berger-Parker Diversity Index (1/d= reciprocal form) and Shannon-Weiner Diversity Index( $H$ ') of the algal class

\begin{tabular}{lll}
\hline Algal class & 1/d & H ' $^{\prime}$ \\
\hline Chlorophyceae & 1.615 & 2.23 \\
Bacillariophyceae & 3.012 & 2.18 \\
Cyanophyceae & 1.138 & 2.01 \\
\hline
\end{tabular}

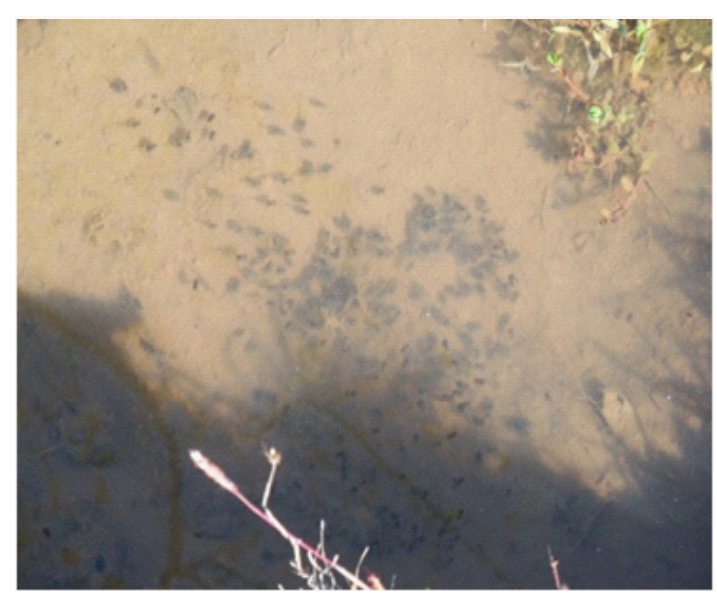

Fig. 1b: Tadpoles of Microhyla ornata

\section{percent abundance}

achlorophyceae abacillariophyceae acyanophyceae detritus UI

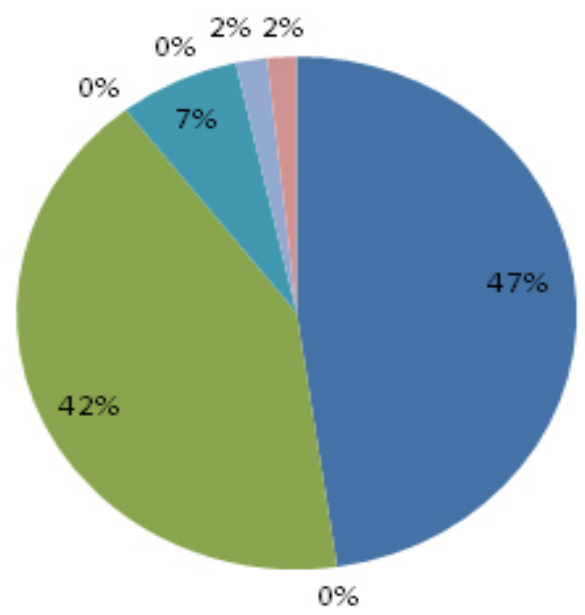

Fig. 2: Relative percent abundance of food items in the gut of Microhyla ornata tadpoles 
Navicula, Gomphonema, and Cymbella were most frequent. The list of all the food items found in the gut of tadpole and its relative percent abundance and frequency of occurrence is shown in Table.1. Although tadpoles fed randomly but a preference for Chlorophyceae was observed. Relative percent abundance of Cyanophyceae was comparatively poor as shown in Figure 1. Detritus was present in the guts of all the individuals and relative frequency of occurrence was $50 \%$. Detritus has been recognized as a potentially important food resource for a wide variety of aquatic organism (Ahlgren, 1990b) and is selected intentionally and not ingested incidentally as in fish (Ahlgren, 1990a). Euglenophyceae and zooplankton was totally absent in the gut of the tadpoles of Microhyla ornata, which reveals some extent of selectivity. However, zooplanktons were also not detected in the water sample of the system.

In Chlorophyceae, 14 different food items have been recorded. The most frequently occurring species was Closterium sp followed by Cosmarium $s p$ and Euastrum sp. The most important and most preferred food item in Bacillariophyceae is Pinnularia sp. It was found to be present $100 \%$, followed by Navicula and Gomphonema. Eunotia $s p$ and Nitzschia sp were recorded to be poorest in selection by the tadpoles Among cyanophyceae diversity was less as unidentified filamentous bluegreen algae were found to be most abundant as well as most frequent. Oscillatoria sp. and Nostoc $s p$. were identified.

An estimate of food diversity based on Shannon-Weiner Index was 2.37 and the reciprocal form of the Berger- Parker Diversity Index was 3.26 and Species Evenness was recorded as 0.31 (Table 2). Also food diversity of each algal class based on the reciprocal form of the Berger- Parker Diversity Index and Shannon-Weiner Index is presented in Table 3. Estimates of food diversity based on the reciprocal form of the Berger-Parker Diversity Index as well as Shannon-Weiner Diversity Index reveal that the greatest degree of dominance in food items occurs in Bacillariophyceae and the highest species diversity found in Chlorophyceae. Species Evenness $(E)$ is constrained between 0 and 1.0 with 1.0 representing a situation in which all species are equally abundant. The present study reveals that all species are not equally abundant.

From the qualitative analysis of the food items present in the water sample it was found that maximum of the food items found in the gut of the tadpole of Microhyla ornata are similar with that of water sample analysed. Table 4 presents a qualitative list of organisms found in the water sample collected from the habitat of the $M$. ornata tadpoles. Ecallocystis $s p$. detected in the gut of one tadpole was however not detected in the water sample and Spirulina sp. found in water was not detected in the

Table 4: Qualitative list of organisms found in the water sample of the habitat of Microhyla ornata tadpoles

\begin{tabular}{|c|c|c|}
\hline Chlorophyceae & Bacillariophyceae & Cyanophyceae \\
\hline $\begin{array}{l}\text { Spirogyra } s p . \\
\text { Closterium } s p . \\
\text { Pediastrum } s p . \\
\text { Docidium } s p . \\
\text { Mougeotia } s p . \\
\text { Scenedesmus } s p . \\
\text { Ulothrix } s p . \\
\text { Zugnema } s p . \\
\text { Volvox } s p . \\
\text { Euastrum } s p . \\
\text { Ankiosdesmus } s p . \\
\text { Stuarstrum } s p . \\
\text { Cosmarium } s p .\end{array}$ & $\begin{array}{l}\text { Navicula sp. } \\
\text { Pinnularia } s p . \\
\text { Tabellaria } s p . \\
\text { Eunotia } s p . \\
\text { Cymbella } s p . \\
\text { Cyclotella } s p . \\
\text { Gomphonema } s p . \\
\text { Nitzschia } s p .\end{array}$ & $\begin{array}{c}\text { Oscillatoria } s p . \\
\text { Spirulina } s p . \\
\text { Nostoc sp. } \\
\text { Unidentified filamentous algae }\end{array}$ \\
\hline
\end{tabular}


gut. Further study of water sample is necessary for more definite understanding of selective feeding.

Foraging behaviour is an essential component for reproductive success (Nishimura, 1999). In this study, the guts of all the individual tadpoles examined were filled with ingested materials, indicating that tadpoles of Microhyla ornata were continuous feeders, as shown in several studies on other species (Jenssen, 1967; Warkentin, 1992, Dey, 2008).

Tadpoles fed randomly but preferred Navicula sp., and Pinnularia sp. Diatoms like Navicula sp., Pinnularia sp., remain suspended in water and were found in good percentage, this in turn indicates that the tadpoles are specialized for suspension feeding as well as in grazing on roots of various aquatic vegetation, rocks and weeds found in the habitat (Sekar, 1992). The feeding behavior of the tadpoles also ensured some spatial habitat separations. Microhyla ornata tadpoles remained floating and suspended in clean water (Khan and Mufti,1995) and fed on suspended food items. In the present study the tadpoles of Microhyla ornata were clearly visible in the upper strata of the water body. Duellman and Trueb (1986) commented that food partitioning among anuran tadpoles is caused by differences in the ability of the various species to ingest particles of varying size and the position they occupy in the water column.

The unidentified items found in the gut of the Microhyla ornata tadpoles could not be recognized which was because of partially digested condition. The present study reveals that tadpoles of Microhyla ornata are herbivorous, feeding mainly on different algal genera. However, no preference could be observed. Similar result was also found by Dey (2008) and Narzary (2012). Diet selection is dependent on availability of resource, microhabitat and feeding behaviour of the tadpoles, similar observation was also made by Feres et.al (2004).

Knowledge about feeding behaviour is necessary from conservation point of view as only a habitat with adequate food can ensure successful survival of the tadpoles. Habitat degradation and scarcity of food may result in poor survival which in turn will affect the population of anurans in nature. Recent release of IUCN in 2012 on Red List of Threatened species has included 41 amphibian species as threatened with extinction and 18 species as critically endangered (IUCN, Red List, 2012). It is therefore essential to conserve the aquatic habitats which form the most important component for reproduction and successful completion of lifecycle. Awareness among the people need to be generated regarding the significance of anurans in ecosystem so that conservation strategies can be formulated and executed with the help of the local people.

\section{ACKNOWLEGDEMENT}

Authors express their gratitude to UGC, New Delhi for providing financial support.

\section{REFERENCES}

1. Saidapur S. K., Behavioral ecology of anuran tadpoles: The Indian scenario; Proc. Indian Natl. Sci. Acad. B; 67, 311-322 (2001)

2. Sinha B., Chakarvorty P., Borah M. M, and Bordoloi S., Qualitative analysis of food spectrum of five species of anuran tadpoles from Arunachal Pradesh, India. Zoosprint Journal, 16(6): 514-515 (2001)

3. Duellman W.E. and Tureb L., Biology of amphibians. Newyprk, McGraw Hill Book Company, XVII: 670 (1986)

4. Kupferberg S. J., Marks J. C. and Power M. E., Effects of variation in natural algal and detrital diets on larval anuran (Hyla regilla) life history traits. Copeia, 2 : 446-457 (1994)

5. Heyer W. R., Food item analysis of some tadpole populations from Thailand. Herpetologica, 4 : 127 (1972)

6. Seale D.B. and Beckvar N., The comparative ability of anuran larvae (genera: Hyla, Bufo and Rana) to ingest suspended blue- green algae, Copeia , : 495- 503 (1980)

7. Chanda S. K., Food and feeding habits of some amphibian species of Northeast India. Records of the Zoological Survey of India, 93(1-2):15-29 (1993) 
8. Bordolai S. and Kalita S. N., Food habits of five salientian amphibians in Arunachal Pradesh. Hima Vikas Occassional Publication, 11: 134137 (1998)

9. Dey M., Food habits of anuran larvae from Barak Valley, North-eastern India. Hamadryad, 33:107-117 (2008)

10. Narzary J. and Bordoloi S., A Study on certain common pond breeding Anurans and their tadpoles in a pond of Western Assam, India. International Journal of Advanced Biological Research, 2(2) : 342-348 (2012)

11. Smith G.M., Manual of Phycology, An Introduction to the Algae and their Biology Scientific Publishers, (1994)

12. Ahlgren M. O., Nutritional significance of facultative detrivory to the juvenile white sucker (Catostomus commersoni). Can. J. Fish. Aquat. Sci., 47: 49-54 (1990b)

13. Ahlgren M. O., Diet selection and the contribution of detritus to the diet of the juvenile white sucker (Catostomus commersoni). Can. J. Fish. Aquat. Sci., 47 :41-48 (1990a)
14. Nishimura K., Exploration of optimal giving up time in uncertain environment: sit and wait forager. J. Theor. Biol., 199: 321-327 (1999)

15. Jessen T. A., Food habits of the green frog, Rana clamitans, before and during metamorphosis. Copeia,1: 214-218 (1967)

16. Warkentin K. M., Effects of temperature and illumination on feeding rates of green frog tadpoles (Rans clamitans). Copeia, 3: 725730 (1992)

17. Sekar A. G., A study of the food habits of six anuran tadpoles. Journal of the Bombay Natural history Society, 89(1): 9-16 (1992)

18. Khan M.S. and Mufti S. A., Oropharyngeal morphology of detritivorous tadpoles of Rana cyanophlyctis Schneider, and its ecological correlates. Pakistan Journal of Zoology, 27: 43-49 (1995)

19. Feres R., Denise de. C., Jim J. and Fonseea M. G., Diet of tadpoles from temporary pond in Southern Brzil (Amphibia, Anura). Revista Brasileira de Zoologia, 21(4): 745-754 (2004) 